\title{
Hypertension and Excretion of 1-Oxygenated Steroids
}

\author{
R. W. H. EDWARDS, D. R. HARVEY, and E. KNIGHT-JONES* \\ From the Institute of Child Health, University of London, 30 Guilford Street, London W.C.1, and \\ Nuffield Neonatal Research Unit, Hammersmith Hospital, London W.12
}

Congenital adrenal hyperplasia with failure of 11-hydroxylation (Eberlein and Bongiovanni, 1956) produces virilization and hypertension. The newborn girl reported here was originally thought to have this condition, but investigations revealed an abnormal steroid excretion of a type not previously described. In retrospect it was realized that the type of abnormal steroid which she produced had been found once before in a child (Case 2) who had hypertension of unknown cause.

\section{Case Reports}

Case 1. A child of healthy West Indian parents was born at term at Hammersmith Hospital in August 1966, weighing $3440 \mathrm{~g}$. Her mother had not been given hormones in pregnancy. She had had 3 other children by a previous marriage; of these, 2 are alive and well in the West Indies, and 1 died of 'dysentery' at the age of 6 months.

Enlargement of the clitoris was noted at birth (Fig. 1). The labia were not fused and the urethra and vagina were normally situated. Her blood pressure was 95 $\mathrm{mm}$. $\mathrm{Hg}$ by the flush method. Her electrolytes were measured daily and remained within normal limits (umbilical arterial and venous catheters were in position for the first $\mathbf{4 8}$ hours).

Her progress was uneventful until her blood pressure began to rise on the 5th day of life (Fig. 2). On the 6 th day her blood pressure was $200 / 130 \mathrm{~mm}$. $\mathrm{Hg}$ in the arm and $200 \mathrm{~mm}$. Hg systolic in the leg, and she went into congestive cardiac failure. The clinical diagnosis was congenital adrenal hyperplasia. Suppressive doses of hydrocortisone were administered, together with digoxin, reserpine, and hydrallazine, diuretics and lowsalt milk (Fig. 2). There was no improvement, and on the 7th day she had generalized convulsions. On the 8th day her systolic blood pressure was $275 \mathrm{~mm}$. Hg, and there was no response to intravenous phentolamine $0.5 \mathrm{mg}$. Pentolinium temporarily controlled her hypertension which was finally reduced to 130 to 150 $\mathrm{mm}$. $\mathrm{Hg}$ by large doses of bethanidine. For regular maintenance she was given methyldopa, but it was not possible to withdraw bethanidine completely. She was nursed tilted head up to facilitate the action of the hypotensive drugs.

Received March 20, 1968.

Present address: Middlesex Hospital, London W.1.
The enlargement of the clitoris became gradually less obvious and by the age of 1 month the appearance of the external genitalia was no longer remarkable. The 11-oxygenation index declined to normal by the 20th day, at which time the hypertension was only partially controlled using very large doses of methyldopa and bethanidine.

As tetrahydro-S was not detected in the urine, hydrocortisone was reduced and was tailed off at 7 weeks without any effect on her hypertension. The blood pressure rose to $220 / 120 \mathrm{~mm}$. $\mathrm{Hg}$ during an ACTH stimulation at 13 weeks and then fell again, this time to a lower level. Hypotensive drugs were gradually withdrawn, and without them her blood pressure remained at $95 / 60 \mathrm{~mm}$. $\mathrm{Hg}$.

She had another ACTH stimulation at 6 months, and this time there was no rise in blood pressure. At the time of writing she is aged 16 months; her blood pressure is $105 / 60 \mathrm{~mm}$. $\mathrm{Hg}$, and her mental and physical development are normal. The results of other investigations are shown in the Table.

Her urinary 11-oxygenation index values (Edwards, Makin, and Barratt, 1964), 17-hydroxycorticoids (Few, 1961), and 17-ketosteroids were determined, and paper chromatographic separation of the individual steroids was carried out by the two-dimensional procedure (Edwards, 1962, 1968). Determined values and blood pressure observations are shown in Fig. 2.

Four hitherto unrecognized substances were found in the urine, 2 of them appearing on the two-dimensional chromatogram of corticosteroids (Fig. 3). The other 2

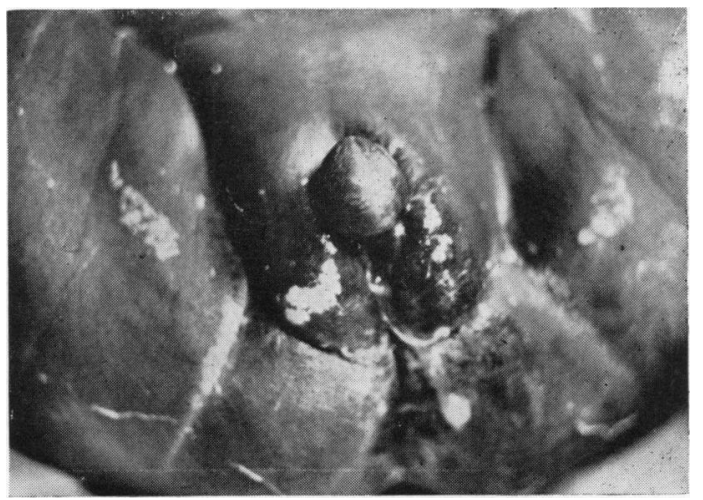

Fig. 1.-Enlargement of the clitoris at birth. 
TABLE

\section{Results of Investigations}

\begin{tabular}{|c|c|c|}
\hline Investigations & Case 1 & Case 2 \\
\hline $\mathrm{Hb}(\mathrm{g} . / 100 \mathrm{ml})$. & $12 \cdot 6$ (at 6 days) & $11 \cdot 3$ \\
\hline Film & Normal & Normal \\
\hline Urine & $\begin{array}{l}\text { No protein, cells, or } \\
\text { casts; cultures } \\
\text { negative; protein } \\
\text { nil }\end{array}$ & $\begin{array}{l}\text { Cellular and } \\
\text { granular casts; } \\
\text { albumin } \\
30-500 \mathrm{mg} . / \\
100 \mathrm{ml} \text {. }\end{array}$ \\
\hline $\begin{array}{l}\text { Maximum urine } \\
\text { concentration }\end{array}$ & s.g. $1 \cdot 024$ & s.g. $1 \cdot 017$ \\
\hline $\begin{array}{l}\text { Amino acid } \\
\text { chromatogram }\end{array}$ & Normal & Normal \\
\hline $\begin{array}{l}\text { Creatinine } \\
\quad \text { clearance } \\
\quad\left(\mathrm{ml} . / \mathrm{min} . \mathrm{m} .{ }^{2}\right)\end{array}$ & 46 (at 2 mth.) & - \\
\hline $\begin{array}{l}\text { Pla3ma urea } \\
\text { (mg./100 ml.) }\end{array}$ & $\begin{array}{l}54 \text { (at } 7 \mathrm{dy} . \text { ), rising } \\
\text { to } 158 \\
47 \text { (at } 5 \mathrm{mth} \text {.) }\end{array}$ & 42 \\
\hline Plasma Na (mEq/1.) & 133 & 132 \\
\hline Plasma K (mEq/l.) & $4 \cdot 9$ & $6 \cdot 4$ \\
\hline $\begin{array}{l}\text { Plasma Cl } \\
(\mathrm{mEq} / \mathrm{l} .)\end{array}$ & 103 & 103 \\
\hline $\begin{array}{l}\text { Plasma HCO }_{3} \\
(\mathrm{mEq} / \mathrm{l} .)\end{array}$ & 19 & 16 \\
\hline $\begin{array}{l}\text { Plasma Ca } \\
(\mathrm{mEq} / \mathrm{l} .)\end{array}$ & $5 \cdot 8$ & $5 \cdot 1$ \\
\hline $\begin{array}{c}\text { Plasma Mg } \\
\text { (mEq/1.) }\end{array}$ & 2 & - \\
\hline $\begin{array}{l}\text { Urinary VMA } \\
(\mu \mathrm{g} . / \mathrm{ml} .)\end{array}$ & 1 & Normal \\
\hline $\begin{array}{l}\text { Intravenous } \\
\text { pyelogram }\end{array}$ & $\begin{array}{l}\text { Good excretion by } \\
\text { left kidney; no } \\
\text { excretion on right } \\
\text { (at } 3 \text { wk.); repeat } \\
\text { (12 wk.) } 2 \text { normal } \\
\text { kidneys; long } \\
\text { axes: right } 5 \cdot 7 \\
\text { cm., left } 6 \cdot 5 \mathrm{~cm} \text {. }\end{array}$ & $\begin{array}{l}\text { Normal kidneys } \\
\text { and ureters }\end{array}$ \\
\hline $\begin{array}{l}\text { Retrograde } \\
\text { aortogram }\end{array}$ & $\begin{array}{l}\text { Both renal arteries } \\
\text { filled well }(6 \mathrm{wk} .) ; \\
\text { suggestion that } \\
\text { intrarenal arteries } \\
\text { on right were } \\
\text { slightly crowded, } \\
\text { but may have been } \\
\text { due to rotation }\end{array}$ & $\begin{array}{l}\text { Normal aorta and } \\
\text { renal } \\
\text { vasculature }\end{array}$ \\
\hline ECG & $\begin{array}{l}\text { Right and left } \\
\text { ventricular } \\
\text { hypertrophy, no } \\
\text { hypokalaemic } \\
\text { changes }\end{array}$ & $\begin{array}{l}\text { Left ventricular } \\
\text { hypertrophy }\end{array}$ \\
\hline $\begin{array}{l}\text { Plasma renin } \\
(U / 1 .)^{\star}\end{array}$ & 87 & \\
\hline $\begin{array}{l}\text { Pressor amines } \dagger \\
(\mu \mathrm{g} . / \mathrm{ml} .)\end{array}$ & $\begin{array}{l}\text { When BP } 250 \mathrm{~mm} \text {. } \\
\text { Hg, } 0 \cdot 1-0 \cdot 15 \\
\text { (normal); BP } \\
140-150 \mathrm{~mm} . \mathrm{Hg} \text {, } \\
0 \cdot 1-0 \cdot 15 ; \mathrm{BP} \\
140-150 \mathrm{~mm} . \mathrm{Hg}, \\
>0.2\end{array}$ & \\
\hline $\begin{array}{l}\text { Pupil response to } \\
2 \cdot 5 \% \text { mecholyl }\end{array}$ & Normal & \\
\hline Buccal smear & $\begin{array}{l}32 \% \text { of cells } \\
\text { chromatin-positive }\end{array}$ & \\
\hline
\end{tabular}

* Normal value in adults $8 \cdot 2 \pm 2 \cdot 7(\mathrm{SD})$ units/litre. There has been no study on the newborn using the method of Brown et al. (1965).

† Moulton and Willoughby (1955). were in the highly polar fraction. All have been partially chemically characterized (Edwards and Trafford, 1968).

Case 2. A 2-year-old boy from Kuwait, whose parents and younger sister were in good health, was himself well until the age of 6 months when he became breathless at times; at the age of 16 months he was admitted to hospital in Kuwait in cardiac failure, with a blood pressure of $190 / 120 \mathrm{~mm}$. Hg. At the age of 2 years he was admitted to this hospital under the care of Dr. Bonham Carter.

On admission his blood pressure was $200 / 120 \mathrm{~mm}$. Hg. He had good femoral pulses. His fundi showed early hypertensive changes and his heart was enlarged. No abnormality of the external genitalia was noted. The results of other investigations are shown in the Table.

The urine 17 -ketosteroids were $1.5 \mathrm{mg}$. $/ 24 \mathrm{hr}$., with an 11-oxygenation index of $0 \cdot 7$. In the two-dimensional chromatogram of his urine, there was an abnormal spot which appeared to be identical with the spot produced by the abnormal substances on the chromatogram (Fig. 3) of Case 1.

The boy was put on spironolactone without any fall in blood pressure. His hypertension was partially controlled with bethanidine and diuretics, and he returned to Kuwait. Efforts to trace him have so far been unsuccessful.

\section{Discussion}

The problem of treating hypertensive encephalopathy in the neonatal period is seldom encountered. Reserpine and hydrallazine, generally useful in older children, had no effect on our patients' blood pressure. It seemed preferable to use several hypotensive drugs rather than increase ganglionblocking agents to a dosage which would produce ileus. It is important to position the child tilted as near as possible to vertical.

The subject of hypertension in childhood has been reviewed by McCrory and Nash (1952), Haggerty, Maroney, and Nadas (1956), and Lloyd Still and Cottom (1967) who emphasize that it is usually secondary to some underlying abnormality. Among the rare causes of childhood hypertension are renal artery thrombosis which occurs in the newborn (Woodard, Patterson, and Brinsfield, 1967), lead poisoning (Nadas, 1963), mercury poisoning (Warkany and Hubbard, 1951), hypercalcaemia (Schlesinger, Butler, and Black, 1956), Wilm's tumour (McCrory and Nash, 1952), familial dysautonomia (where the pupil responds abnormally to mecholyl (Dancis and Smith, 1966)), ovarian agenesis without coarctation (Wilkins, 1965), and phaeochromocytoma (Greenberg and Gardner, 1959). Neither of our patients had the hypokalaemic alkalosis common in primary aldo- 

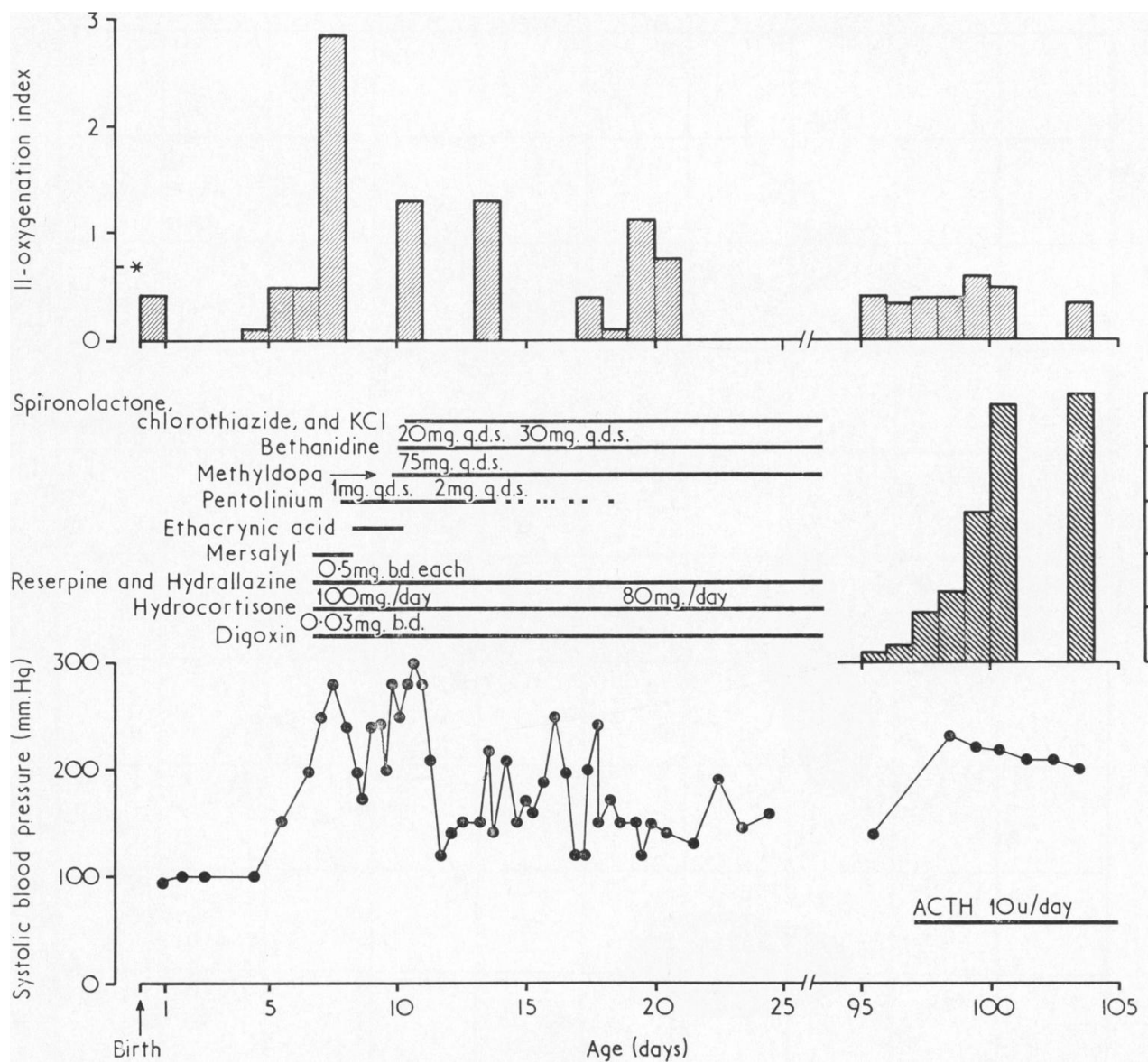

Fig. 2.-Blood pressure, treatment schedule, and steroid parameters for Case 1. *Upper limit of normal value of 11-oxygenation index (Edwards et al., 1964).

steronism (Conn, 1961), and Case 1 had a high plasma renin which virtually excludes it (Brown et al., 1965). Neither child had the facies of Cushing's syndrome, and the 24-hour 17-hydroxycorticoids in Case 1 were low.

Failure of 11-hydroxylation in adrenal hyperplasia leads to virilization and hypertension, with the excretion of tetrahydro-S in the urine. Recently a new form of adrenal hyperplasia has been described (Biglieri, Herron, and Brust, 1966; New and Peterson, 1967; Goldsmith, Solomon, and Horton, 1967; Mills et al., 1967), the clinical features of which are hypogonadism, hypertension, hypokalaemia, low plasma renin, and increased urinary excretion of tetrahydro-DOC. These abnormalities can be corrected by the administration of glucocorticoids, and investigations point to a deficiency of steroid $17 \alpha$-hydroxylase.
In Case 1 the 17-ketosteroid value of $1.8 \mathrm{mg}$./ $24 \mathrm{hr}$. on the 8th day of life could not be considered to be abnormal (Migeon, Keller, and Holmstrom, 1955). Subsequent values were very low (58th, $62 \mathrm{nd}$, and 82nd day), and during this time of growth the earlier enlargement of the clitoris became less obvious. The raised 11-oxygenation index value coincided with the beginning of treatment with reserpine and cortisol. These events may have been related to the onset of hepatic reductive inactivation and conjugation with glucuronic acid.

Chromatographic investigation (Fig. 3) of the nature of the substances contributing to the non11-oxygenated steroid zone on the 11-oxygenation index chromatogram indicated that cortisol biosynthesis was intact, since neither the 11-deoxycortisol metabolite (THS) nor 21-deoxy steroids 


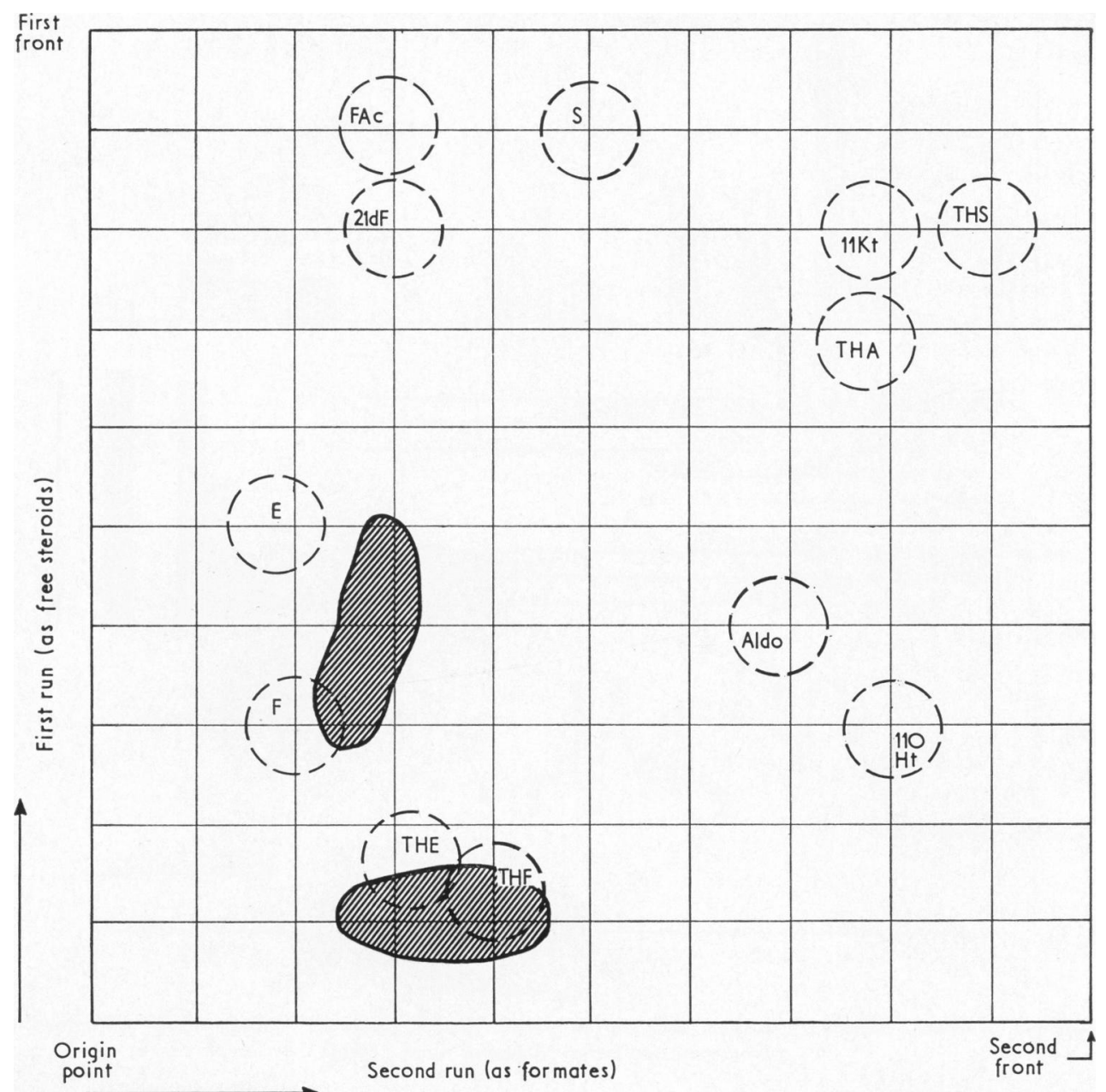

FIG. 3.-Diagram indicating positions reached by corticosteroids in two-dimensional chromatography (Edwards, 1968). The cross lines mark 10's of $R f(\%)$ units, the origin was bottom left-hand corner, the front of the first run (ascending) was at the top $100 \%$ line. The dotted lines mark spots of reference steroids - F, cortisol; $E$, cortisone; Aldo, aldosterone; S, 11-deoxycortisol; FAc, cortisol 21-acetate; 21dF, 21-deoxycortisol; THF, tetrahydrocortisol; THE, tetrahydrocortisone; THS, tetrahydro-11-deoxycortisol; THA, tetrahydro-11-dehydro-corticosterone; 110Ht, 11ß-hydroxypregnanetriol; 11Kt, 11-oxopregnanetriol. The hatched spots mark steroids from the urine of Case 1; THE and THF near the reference spots and substances designated $\mathrm{H1}$ and $\mathrm{H2}$, which were resolved on further chromatography.

(e.g. pregnanetriol) were detected. Four other substances were isolated after extensive purification (Edwards and Trafford, 1968), and partial characterization indicated that they were $5 \beta$-pregnane- $1 \beta$ : $3 \alpha: 17 \alpha: 20 \alpha$-tetrol; $3 \alpha: 17 \alpha: 20 \alpha$-trihydroxy-5 $\beta$-pregnane-1-one; $3 \alpha: 17 \alpha$-dihydroxy-5 $\beta$-pregnane-1:20dione, (H2, Fig. 3), and $17 \alpha$-hydroxy- $5 \beta$-pregnane$1: 3: 20$-trione (H1).

While 7 healthy newborn babies did not excrete these substances, it would be premature to associate the excretion by these patients with the hypertension. In Case $1, \mathrm{ACTH}$ stimulation produced a rise in blood pressure but no significant rise in 11-oxygenation index or the new substances. Furthermore, disappearance of the abnormal steroid antedated the remission of the hypertension by 10 weeks. On the other hand, it is possible for steroids to have a prolonged effect on blood pressure, persisting long after the administered steroid would be metabolized (Green et al., 1952). 
The relation between hypertension and the adrenal cortex has often been considered, usually concerning the action of aldosterone or deoxycorticosterone (Ross, 1959) or changed mode of conjugation (Kornel and Takeda, 1967). Perhaps the present observations indicate new directions of search.

1-oxygenated steroids have not previously been described in man. It is interesting that $1 \alpha$-hydroxycorticosterone, the principal plasma corticoid of the skate, has been shown to be $70 \%$ as active as DOC in promoting sodium retention in the rat (Idler, Freeman, and Truscott, 1967); in this instance the addition of a l $\alpha$-hydroxyl group converted corticosterone (which has only minor effects on electrolyte balance) into a potent mineralocorticoid. The substances at present under study have dissimilar side chains to the skate corticosteroid, being 17:20 dioxygenated instead of $20: 21$. This type of structural difference divides the glucocorticoids and the mineralocorticoids among the 11-oxygenated steroids. It seems possible that in the 2 children described here the hypertension may have been related to the presence of the 1-oxygenated substances.

We hope to study the excretion of these substances by other hypertensive children and adults in comparison with healthy subjects, and to extend investigations to work with experimental animals to determine the biological properties of 1-hydroxy pregnane derivatives.

We are grateful to Professor J. P. M. Tizard and Dr. R. E. Bonham Carter for permission to publish these cases; to Professor W. S. Peart, Dr. J. J. Brown, Dr. D. L. Davies, Dr. A. F. Lever, and Dr. J. I. S. Robertson of St. Mary's Hospital for plasma renin and catecholamine estimations; and to Professor M. L. Rosenheim and Dr. C. J. Dickinson of University College Hospital for pressor amine estimation.

\section{Appendix}

Identification of Urinary Steroids by Twodimensional Chromatography.

Urinary conjugates were hydrolysed and the steroids extracted and partially purified, as described elsewhere (Edwards, 1968). Paper chromatography using methanol: water: light petroleum::80:20:100 at $37^{\circ} \mathrm{C}$. after 1 hour equilibration, was followed by second chromatography in the perpendicular direction using formic acid:benzene:light petroleum::100:30:70 at room temperature with 4 hours' equilibration.

Steroids were located by absorption of $254 \mathrm{~m} \mu$ light, tetrazolium reduction, and the ketogenic reagents applied in sequence. The positions reached by reference steroids and the urinary 1-oxygenated steroids are shown in Fig. 3.

\section{REFERENCES}

Biglieri, E. G., Herron, M. A., and Brust, N. (1966). 17-hydroxylation deficiency in man. $\mathcal{F}$. clin. Invest., 45, 1946.

Brown, J. J., Davies, D. L., Lever, A. F., and Robertson. J. I. S. (1965). Plasma renin concentration in human hypertension. II. Renin in relation to aetiology. Brit. med. $\mathcal{F} ., 2,1215$.

Conn, J. W. (1961). Aldosteronism and hypertension. Arch. intern. Med., 107, 813.

Dancis, J., and Smith, A. A. (1966). Familial dysautonomia. New Engl. F. Med., 274, 207.

Eberlein, W. R., and Bongiovanni, A. M. (1956). Plasma and urinary corticosteroids in the hypertensive form of congenital adrenal hyperplasia. f. biol. Chem., 223, 85 .

Edwards, R. W. H. (1962). Two-dimensional chromatography of corticosteroids. Biochem. $\mathcal{F}$., 82, 48p.

- (1968). In Chromatographic and Electrophoretic Techniques, 3rd ed., Vol. 1, Chapter 23, p. 538. Ed. by I. Smith. Heinemann, London.

-, Makin, H. L. J., and Barratt, T. M. (1964). The steroid 11oxygenation index: a rapid method for use in the diagnosis of congenital adrenal hyperplasia. F. Endocr., 30, 181.

- and Trafford, D. (1968). The partial characterization of 1-oxygenated steroids from urine of a hypertensive, newborn child. Biochem. F., 108, 185.

Few, J. D. (1961). A method for the analysis of urinary 17hydroxycorticosteroids. $\mathcal{F}$. Endocr., 22, 31.

Goldsmith, O., Solomon, D. H., and Horton, R. (1967). Hypogonadism and mineralocorticoid excess: the 17-hydroxylase deficiency. New Engl.F. Med., 277, 673.

Green, D. M., Saunders, F. J., Wahlgren, N., and Craig, R. L. (1952). Self-sustaining, post-DCA hypertensive cardiovascular disease. Amer.F. Physiol., 170, 94.

Greenberg, R. E., and Gardner, L. I. (1959). Pheochromocytoma in father and son: report of the eighth known affected kindred. F. clin. Endocr., 19, 351 .

Haggerty, R. J., Maroney, M. W., and Nadas, A. S. (1956). Essential hypertension in infancy and childhood. Amer. $\mathcal{F}$. Dis. Child., 82, 535.

Idler, D. R., Freeman, H. C., and Truscott, J. B. (1967). A preliminary communication on the biological activity of $1 \alpha-$ hydroxycorticosterone isolated from cartelaginous fish. $\mathcal{F}$. Fish. Res. Bd. Can., 24, 1.

Kornel, L., and Takeda, R. (1967). Studies on steroid conjugates : V. Urinary 17-hydroxycorticosteroids in essential hypertension. F. clin. Endocr., 27, 233.

Lloyd Still, J., and Cottom, D. (1967). Severe hypertension in childhood. Arch. Dis. Childh., 42, 34.

McCrory, W. W., and Nash, F. W. (1952). Hypertension in children: A review. Amer.f. med. Sci., 223, 671 .

Migeon, C. J., Keller, A. R., and Holmstrom, E. G. (1955). Dehydroepiandrosterone, androsterone and 17-hydroxycorticosteroid levels in maternal and cord plasma in cases of vaginal delivery. Bull. Fohns Hopk. Hosp., 97, 415.

Mills, I. H., Wilson, R. J., Tait, A. D., and Cooper, H. R. (1967). Steroid metabolic studies in a patient with 17-hydroxylase deficiency. F. Endocr., 38, 19p.

Moulton, R., and Willoughby, D. A. (1955). A short laboratory screening test for phaeochromocytoma. Lancet, $2,16$.

Nadas, A. S. (1963). Pediatric Cardiology, 2nd ed. W. B. Saunders, Philadelphia.

New, M. I., and Peterson, R. E. (1967). A new form of congenital adrenal hyperplasia. f. clin. Endocr., 27, 300 .

Ross, E. J. (1959). Aldosterone in Clinical and Experimental Medicine. Blackwell, Oxford.

Schlesinger, B. E., Butler, N. R., and Black, J. A. (1956). Severe type of infantile hypercalcaemia. Brit.med. $., 1,127$.

Warkany, J., and Hubbard, D. M. (1951). Adverse mercurial reactions in the form of acrodynia and related conditions. Amer. F. Dis. Child., 81, 335.

Wilkins, L. (1965). The Diagnosis and Treatment of Endocrine Disorders in Childhood and Adolescence, 3rd ed. Charles C. Thomas, Springfield, Illinois.

Woodard, J. R., Patterson, J. H., and Brinsfield, D. (1967). Renal artery thombosis in newborn infants. Amer. F. Dis. Child., 114,191 . 